\title{
SIKLUS INFORMASI ARKEOLOGI: \\ Menuju Pemasyarakatan Hasil Penelitian yang Terintegrasi \\ di Balai Arkeologi Ambon*
}

Marlon NR Ririmasse

Tujuan pokok dari Pusat Penelitian Arkeologi Nasional adalah menyelenggarakan penelitian di bidang Ilmu Arkeologi. Suatu kondisi yang keberhasilannya dapat diukur dari jumlah dan kualitas penelitian yang berhasil dilaksanakan (Sedyawati, 2001). Dengan kata lain, hasil penelitian adalah titik tolak bagi publik dalam arti yang seluas-luasnya, untuk mengapresiasi kinerja Pusat Penelitian Arkeologi Nasional. Sejalan dengan kenyataan tersebut, pemasyarakatan hasil penelitian arkeologi adalah suatu keharusan sebagai bentuk pertanggungjawaban lembaga penelitian kepada pemerintah dan masyarakat.

\section{Publikasi Arkeologi: Mengapa Ke Masyarakat ?}

Publikasi hasil penelitian adalah salah satu jembatan penghubung bagi lembaga penelitian bersama segala aktifitasnya dengan publik. Termasuk di dalamnya aktifitas penelitian yang dilakukan lembaga kedinasan resmi seperti Puslit dan Balai Arkeologi. Tanpa pemasyarakatan hasil penelitian, dapat dikatakan alur penelitian yang dilakukan suatu lembaga belumlah lengkap. Sebagai instansi pemerintah, berbagai kegiatan penelitian arkeologi Puslit dan BalarBalarnya pada dasarnya dibiayai oleh masyarakat melalui pajak yang dibayarkan. Sudah pada tempatnyalah, semua lembaga ini bersama para arkeolognya melaporkan kembali dan mengembalikan apa yang telah dikerjakannya kepada masyarakat (Thajono, 2004).

Kedua, tujuan pemasyarakatan hasil penelitian tentu tidak lepas dari upaya untuk menciptakan Pusat Penelitian Arkeologi Nasional sebagai 'institusi rancang bangun pengetahuan arkeologi' yang utuh. Tanpa apresiasi publik, hasil penelitian jelas masih timpang dan belum

* Makalah ini pernah disampaikan dalam Evaluasi Hasil Penelitian Arkeologi pada tahun 2006 yang diselenggarakan oleh Pusat Penelitian Arkeologi Nasional 
utuh. Makin luas dan makin berkualitas bentuk apresiasi masyarakat, secara tidak langsung makin membuat posisi Pusat Penelitian Arkeologi Nasional (termasuk juga Balar) lebih terakui. Bahwa pemasyarakatan hasil penelitian adalah bagian integral yang tidak terpisahkan dari lembaga, sudah dituangkan dalam visi dan misi Pusat Penelitian Arkeologi Nasional. Visi Pusit adalah "Terwujudnya lembaga penelitian yang mampu mengembangkan dan memasyarakatkan arkeologi untuk kemajuan ilmu pengetahuan, pencerdasan bangsa, dan pengembangan budaya nasional" (Simanjutak dkk, 2003). Dalam posisi ini dapat dikatakan puslit (bersama Balai Arkeologinya) menjadi salah satu agen atau mediator untuk pencerdasan kehidupan bangsa dan pengembangan budaya nasional salah satunya melalui pemasyarakatan hasil penelitian yang telah dilakukan. Rancangan Induk Penelitian Arkeologi nasional menyatakan, bahwa Puslit memiliki dua kegiatan 'industri' inti. Kegiatan pertama adalah industri hulu dalam bentuk penelitian yang telah menjangkau berbagai pelosok nusantara. Kegiatan kedua adalah industri hilir, dimana Puslit telah menghasilkan berbagai karya ilmiah sebagai wujud pertanggungjawabannya kepada masyarkat, khususnya masyarakat ilmiah. Pada level 'industri hilir' inilah dilakukan berbagai kegiatan yang bertujuan memasyarakatkan hasil-hasil penelitian (Ibid).

Gambaran tugas ini dinyatakan dengan lebih jelas dalam misi Puslit sebagaimana tertuang dalam poin ke dua yaitu "memasyarakatkan hasil-hasil penelitian". Misi pemasyarakatan merupakan konsekwensi dari misi pertama yaitu penelitian, sebagai bentuk pertanggungjawaban ilmiah dari kegiatan penelitian yang telah dilakukan. Melalui pemasyarakatan hasil penelitian Puslit tidak hanya menyampaikan pengetahuan tentang kandungan nilai akademis dalam penelitian, namun juga menyampaikan kandungan nilai strategis penelitian yaitu identifikasi nilai-nilai luhur budaya bangsa. Kenyataan di atas dipertegas dalam tugas pokok Puslit yang salah satunya menyatakan bahwa tugas puslit adalah "mengolah dan menyebarluaskan hasil penelitian dalam berbagai sarana dan media".
Marlon Ririmasse, Siklus Informasi : Menuju Pemasyarakatan Hasil Penelitian yang Terintegrasi .......

Arkeologi yang berubah: Menciptakan Ruang Bagi Masyarakat

Pada dasarnya arkeologi tidak mungkin untuk dilepaskan dalam fungsi dan perannya dari masyarakat. Komunitas arkeologi berserta seluruh sumber daya yang ada padanya adalah bagian integral dalam masyarakat secara umum. Sehingga tidak dapat dipungkiri bahwa interaksi antara arkeologi dan masyrakat sangat kental. Tjahjono (2004) menyatakan bahwa terdapat tiga pihak utama yang berperan dalam perkembangan arkeologi (setidaknya di Indonesia) yaitu pihak akademisi, pihak pemerintah, dan pihak masyarakat. Ketiganya memiliki peran yang sama-sama menentukan bagi keberlangsungan arkeologi. Akademisi adalah garda depan dalam pembentukan sumber daya arkeologi di Indonesia meliputi konsep dan manusia. Pemerintah, dalam hal ini lembaga kedinasan (Puslit, Balar, BP3) memiliki 'peran tengah' untuk menjalankan fungsi pengembangan arkeologi dalam konteks penelitian, pemasyarakatan, pelestarian dan pemanfaatan sumber daya arkeologi. Masyarakat, di atas akademisi dan pemerintah, sesungguhnya adalah pemilik sebenarnya sumber daya budaya (arkeologi) sejalan dengan kedudukan masyarakat sebagai muara dari semua kebijakan pemerintah.

Adalah suatu kenyataan bahwa meski berada dalam satu lingkaran interaksi, posisi komunitas arkeologi dan masyarakat non arkeologi jelas tetap berbeda. Setidaknya dalam konteks bidang (ilmu) arkeologi, di mana komunitas internal arkeologi telah dibekali dengan perangkat pengetahuan yang tentu mempengaruhi cara pandangnya terhadap apa yang disebut sebagai sumber daya arkeologi. Sebaliknya masyarakat, meski dari perangkat intelektual arkeologinya tidak 'secanggih" komunitas internal arkeologi, harus diakui memiliki peran yang sama besar dengan komunitas internal arkeologi. Tanudirdjo menyatakan, Sumber daya arkeologi pada dasarnya adalah milik masyarakat, sehingga sudah pada tempatnya bila masyarakat mendapatkan porsi benefit yang terbesar dalam perkembangan arkeologi di Indonesia.

Kondisi ini seharusnya mendorong komunitas internal arkeologi untuk berusaha memberdayakan masyarakat. Masyarakat awam, sebagaimana telah disebutkan di atas, pada dasarnya memang tidak memiliki perangkat pengetahuan/kerja arkeologi (Archaeology

Kapata Arkeologi Vol. 4 Nomor 7 / November 2008 
Scientific Tools) sebagaimana halnya para arkeolog. Meski demikian, masyarakat selalu berinteraksi, langsung ataupun tidak, dengan sumber daya budaya beserta segenap pengetahuan dan informasinya. Sehingga wajar jika masyarakat juga memiliki cara mereka sendiri dalam memandang dan memberi makna pada suatu sumber daya budaya. Di sinilah kalangan internal arkeologi memainkan peran pemberdayaan tersebut. Yaitu bahwa kalangan internal arkeologi dengan perangkat pengetahuan kerjanya, dapat memposisikan diri sebagai mediator untuk membantu memberi makna sosial sumber daya budaya bagi masyarakat. Dalam arti, arkeologi harus mampu mendorong terciptanya kondisi, di mana segenap sumber daya budaya mampu memberikan sumbangan untuk menjawab berbagai persoalan sosial di masyarakat. Kemampuan arkeologi dalam menemukan perubahan sosial di masa lalu, termasuk faktor-faktor yang mendorong perubahan tersebut, sudah sepantasnya diberi kerangka baru untuk juga mampu menjawab persoalan-persoalan sosial masa kini yang ada di masyarakat. Dengan demikian arkeologi dapat keluar 'sekedar kajian ilmiah masa lalu' memasuki peran yang lebih besar untuk memberi manfaat yang lebih luas bagi masyarakat.

Konsep di atas menurut penulis dapat dimulai oleh kalangan internal arkeologi antara lain dengan belajar untuk selalu memberikan informasiyang benartentang arkeologikepada masyarakat. Benar dalam artian, informasi arkeologi yang disampaikan tentu perlu disajikan sesuai dengan etika dan kaidah-kaidah keilmuan yang seharusnya. Minimal menyajikan secara jujur dan apa adanya sesuai fakta-fakta ilmiah yang ditemukan. Di sisi lain arkeologi harus menyadari bahwa masyarakat terdiri dari berbagai kelompok dengan perbedaan latar belakang sosial budaya dan pendidikan, sehingga strategi dalam menyampaikan informasi arkeologi tentu harus lebih dinamis. Arkeologi harus kreatif dalam memciptakan strategi penyampaian informasi agar sesuai dengan kondisi masyarakat sehingga lebih tepat sasaran, dan terutama mampu memberi manfaat sosial yang sebesarbesarnya bagi masyarakat. Adalah penting bagi komunitas arkeologi untuk mereduksi ego-ego keilmiahan dengan berupaya menampilkan fakta-fakta ilmiah apa adanya dalam menyajikan informasi arkeologi bagi masyarakat. Menjaga kejernihan dalam berwacana adalah jalan untuk menciptakan pemahaman yang benar bagi masyarakat tentang sumber daya arkeologi.

\section{Mediasi Melalui Publikasi}

Dalam konteks interaksi arkeologi dengan masyarakat lua yang telah mengalami reposisi, publikasi arkeologi jelas memainkan peran vital. Publikasi di sini bukan hanya berarti penerbitan saja, tetap mencakup bentuk publikasi informasi arkeologi lain, misalnya display museum, diskusi, ataupun pameran hasil penelitian arkeologi. Dalam lingkup kerjanya Puslit sudah memulainya sejak lama dengan berbagai publikasi hasil-hasil penelitian melalui beragam media salah satunya adalah penerbitan antara lain: Berita Penelitian Arkeologi, Kalpataru, Amerta, Aspek-aspek arkeologi, Monografi, Penerbitan Bergambar, Buletin Pusat Penelitian Arkeologi, serta Porceedings. Balai-balai Arkeologi sebagai perpanjangan tangan Puslit di daerah memiliki tanggung jawab yang sama besar dengan puslit sebagai lembaga induk dalam memasyarakatkan informasi arkeologi. Utamanya bila menilik peran Balar sebagai kontributor terdepan dalam publikasi informasi arkeologi di daerah. Dalam posisi ini sebetulnya Balai Arkeologi memiliki peluang besar untuk melibatkan masyarakat lokal ruang lingkup kajian arkeologi, dan salah satunya dapat dimulai dengan membuka ruang yang lebih luas bagi masyarakat terlibat dalam ragam bentuk proses publikasi arkeologi. Terlibat di sini tentu bukan saja dengan mendudukan masyarakat dalam posisinya dulu dan saat ini (?) yang cenderung berperan sebagai konsumen informasi (atau objek), namun bagaimana berupaya mendorong masyarakat untuk terlibat secara nyata dalam proses produksi publikasi informasi arkeologi. Sangat naif rasanya jika kita berbicara bahwa arkeologi juga harus mempertimbangakan sudut pandang masyarakat dalam memaknakan dan memanfaatkan sumber daya budaya, tanpa berupaya memberi ruang dan sarana bagi pemikiran masyarakat tentang sumber daya budaya. Di sinilah Balai Arkeologi seharusnya mampu berperan sebagai mediator untuk menjawab tantangan tersebut, dengan mengembangkan strategi kreatif yang mampu mengakomodasi aspek sosial masyarakat dalam pemanfaatan sumber daya budaya. 
Pemasyarakatan Hasil Penelitian Balai Arkeologi Ambon: Membangun Visi menjalankan Misi

Balai Arkeologi Ambon, sebagi UPT Puslit di daerah, mengemban tangggung jawab yang sama dengan Balar-Balar lain untuk menyebar luaskan informasi arkeologi dan hasil-hasil penelitian untuk tujuan yang seluas-luasnya. Adalah amanat bagi Balar Ambon untuk mendorong terciptanya kondisi, di mana segenap sumber daya budaya yang ada di wilayah Maluku, mampu memberikan manfaat yang sebesar-besarnya bagi masyarakat Maluku.

Balai Arkeologi Ambon didirikan pada tahun 1995 sesuai Surat Keputusan Menteri Pendidikan dan kebudayan nomor 015/0/1995. Dengan demikian Kedudukan Balai Arkeologi Ambon adalah sebagai Unit Pelaksana Teknis Pusat yang bertugas melaksanakan penelitian arkeologi di wilayah Maluku dan Maluku Utara. Tugas ini dimplementasikan dalam penjabaran fungsi Balai Arkeologi Ambon yang antara lain mencakup

- Melakukan pengumpulan, perawatan, pengawet-an dan penyajian benda yang bernilai budaya dan alamiah yang berhubungan dengan penelitian arkeologi.

- Melakukan urusan perpustakaan, pendokumentasian dan pengkajian ilmiah yang berhubungan dengan penelitian arkeologi.

- Memperkenalkan dan menyebarluaskan hasil penelitian arkeologi.

- Melakukan bimbingan edukatif cultural kepada masyarakat tentang benda arkeologi yang bernilai budaya dan ilmiah.

- Melakukan urusan tata usaha dan urusan rumah tangga Balai Arkeologi.

Keseluruhan fungsi ini dituangkan dalam Visi dan Misi Balai Arkeologi Ambon yaitu:

- Menjadi lembaga penelitian arkeologi di wilayah Maluku yang mampu merencanakan dan melaksanakan penelitian arkeologi secara sistematis di wilayah ini
- Mampu mengembangkan dan memasyarakatkan makna dan pengertian arkeologi dalam arti luas.

- Menampilkan hasil-hasil penelitian arkeologi Maluku bagi kepentingan sejarah kebudayaan nasional dan kemajuan ilmu pengetahun dan peningkatan ketahanan budaya

Sudah jelas dijabarkan di atas bahwa tugas Balai Arkeologi Ambonmencakupjugakegiatanmemperkenalkandanmenyebarluaskan hasil penelitian arkeologi. Sekaligus pada saat yang sama melakukan bimbingan edukatif kultural kepada masyarakat tentang benda arkeologi yang bernilai budaya dan Ilmiah. Implementasi dari fungsi ini dituangkan dalam Visi dan Misi Balai Arkeologi Ambon di atas, yaitu mampu mengembangkan dan memasyarakatkan arekologi dalam arti luas dengan jalan menampilkan hasil-hasil penelitian di Maluku bagi kepentingan sejarah kebudayaan lokal dan nasional, juga memajukan ilmu pengetahuan dan meningkatkan ketahanan budaya (Suantika,2005).

Setelah menjalankan tugasnya hampir lebih dari satu dasawarsa, Balai Arkeologi Ambon dapat dikatakan sudah mencapai kemajuan-kemajuan yang cukup berarti. Utamanya bila menilik dari kegiatan penelitian yang sudah dilakukan di wilayah ini. Harus di akui, kondisi geografis Maluku dan Maluku Utara yang luas dan terdiri dari kepulauan merupakan suatu tantangan tersendiri bagi kinerja Balai Arkeologi Ambon. Sebelum berdirinya Balar Ambon, penelitian di wilayah ini bisa dikatakan sangat minim. Penulis mencatat, hanya ada sekitar sembilan penelitian arkeologis yang dilakukan secara resmi di wilayah ini sebelum berdirinya Balai Arkeologi Ambon. Enam penelitian oleh peneliti nasional dan tiga penelitian oleh peneliti atau lembaga asing. Sesudah Balai Arkeologi didirikan, dapat dikatakan penelitian arkeologi mulai berjalan dengan semestinya. Dalam arti bila ditinjau dari segi kuantitas, bisa nampak adanya perubahan yang berarti. Ada hampir empat puluh penelitian yang sudah dilakukan oleh Balai Arkeologi Ambon (Ririmasse, 2005). Meski bila dibandingkan dengan kekayaan sumber daya budaya di wilayah ini, kegiatan penelitian tentu harus lebih digalakan. Kondisi ini cukup dapat dimaklumi mengingat faktor luasnya wilayah kerja dan minimnya 
tenaga arkeolog cukup menghambat pelaksanaan penelitian. Di samping itu, kondisi daerah Maluku yang sempat terkena konflik sosial hampir empat tahun lamanya, juga sangat mempengaruhi aktifitas penelitian Balai Arkeologi Ambon. Tahun-tahun ke depan, sejalan dengan penambahan tenaga arkeolog di Balai Arkeologi Ambon, diharapkan aktifitas penelitian juga dapat ditingkatkan, bukan saja dari sisi kuantitas, namun juga kualitas. Sehingga penelitian bukan saja berkutat dalam tataran regsitrasi dan dokumentasi, namun juga diharapkan mulai diarahkan pada penelitian yang lebih mendalam dan sistematis.

Kendala yang sama di atas juga berpengaruh pada upaya pemasyarakatan hasil-hasil penelitian. Termasuk upaya memasyaraktkan informasi arkeologi secara luas. Secara jujur harus diakui bahwa selama ini upaya publikasi hasil penelitian dan informasi arkeologi di wilayah kerja Balai Arkeologi Ambon masih sangat minim. Publikasi yang sudah dilakukan selama ini masih sangat internal sifatnya. Hampir semuanya masih berupa laporan penelitian yang sebetulnya dapat dikatakan lebih merupakan'pelengkap' rangkaian penelitian. Cenderung sebagai pelengkap admistratif penelitian sebagai pertanggungjawaban kedinasan. Publikasi dalam bentuk tulisan atau penerbitan yang sifatnya mengarah ke lingkungan luar Balar Ambon sangat minim. Suatu kondisi yang menurut penulis sangat dipengaruhi oleh jumlah tenaga peneliti yang jauh dari memadai saat itu (2 Orang). Minimnya tenaga ahli arkeologi ini akhirnya juga mempengaruhi minimnya bentuk-bentuk publikasi lain seperti sosialiasi, pameran, penyuluhan atau diskusi. Meski demikian, Balar Ambon selalu berupaya semaksimal mungkin menjalan perannya sebagai 'media' informasi arkeologi bagi masyarakat Maluku.

Mulai Tahun 2006 ini Balar Ambon sudah mengambil langkah maju, menyusul Balar-Balar lain,dalam memasyarakatkan hasil penelitian dalam lingkup wilayah kerjanya. Langkah maju ini ditandai dengan penerbitan Berita Penelitian Arkeologi dan Buletin Arkeologi 'Kapata', yang keduanya sudah ber-ISSN. Baik BPA maupun Kapta Balar Ambon, direncanakan terbit secara teratur dua kali dalam setahun dan memuat informasi hasil penelitian yang sudah dilakukan dilingkungan Balar Ambon maupun tulisan arkeologi populer untuk menjangkaukalangan yang lebih luas. Bukan halbaru memang. Apalagi bila menilik pada penerbitan yang sudah jauh lebih lama dilakukan Balar lain. Apapun keadaannya, Balar Ambon sudah memasuki babak baru dengan munculnya penerbitan rutin resmi ini. Minimal sebagai bukti implementasi nyata dari tanggung jawab pemasyarkatan hasil penelitian Balar Ambon. Tahun ini juga Balar Ambon telah melakukan kegiatan Diskusi dan Pameran arkeologi yang merangkul berbagai pihak yang memiliki kompetensi dalam pengelolaan sumber daya budaya di daerah Maluku. Pameran dan diskusi tahun 2006 ini bisa dikatakan sukses bila ditilik dari sudut pandang publikasi arkeologi. Utamanya bila menilik berbagai pihak yang berperan dalam kegiatan ini. Terlibat dalam diskusi ini, rekan-rekan dari Dinas terkait seperti Bid Musjarla, Museum, Universitas lokal, Balai Kajian Sejarah dan Nilai Tradisional, Lembaga Kebudayaan Daerah, serta Pemda melalui Dinas Pariwisata Propinsi. Balar Ambon juga merangkul rekanrekan organisasi masyarakat, komunitas adat lokal (para'raja') dan yang terpenting komunitas pendidikan, pelajar dan guru. Sambutan rekan-rekan media juga sangat menggembirakan sebagaimana terlihat dari jumlah media yang meliput kegiatan diskusi dan pameran. Di samping kegiatan di atas, Balar Ambon juga melakukan kegiatan publikasi rutin yang sudah dilakukan secara teratur selama ini yaitu sosialisasi. Kegiatan ini utamanya diarahkan pada segmen pelajar dan lingkungan pendidikan. Balar Ambon juga sudah mulai berinteraksi dengan media-media elektronik lokal seputar isu-isu sejarah lokal dan pemanfaatan sumber daya budaya.

Penerbitan, Diskusi, dan Pameran yang sudah dilakukan dapat dikatakan sebagai langkah awal Balar Ambon dalam upayanya membuka diri untuk lebih memasyarakatkan arkeologi di wilayah Maluku. Tentu ke depan akan terus dilakukan pembenahanpembenahan internal agar produk-produk publikasi hasil penelitian arkeologi Balar Ambon mampu memberikan manfaat yang lebih besar dan lebih luas untuk pembangunan daerah dan terutama membantu masyarakat dalam menjawab persoalan-persoalan sosial yang muncul. 
Tantangan dan Peluang: Membuka Diri, Menciptakan Strategi

Informasi tentang sumber daya budaya seharusnya menjadi isu yang menjangkau semua elemen publik yang terkait baik pemerintah, akademisi dan tentu masyarakat. Adalah tugas Balar Ambon untuk menjalankan fungsi mediator guna menciptakan interaksi yang sinergis antara semua elemen terkait guna pengembangan sumber dayadi wilayah Maluku.

Dalam upaya menciptakan pemasyarakatan hasil penelitian yang terintergrasi di dilayah Maluku, Balar Ambon setidaknya dihadapkan pada tiga tugas yang dapat dirangkum sebagai berikut:

- Mampu menjadi jembatan antara sumber daya budaya (arkeologi) dan masyarakat. Dalam arti publikasi arkeologi harus menjadi sarana bagi arkeologi untuk secara maksimal mampu memediasi upaya pemanfaatan sumber daya budaya bagi kepentingan masyarakat Maluku yang seluas-luasnya. Untuk mencapai tujuan ini arkeologi harus lebih membuka diri terhadap sudut pandang masyarakat dalam menilai dan memberi makna pada sumber daya budaya. Pada tingkat yang lebih lanjut, publikasi arkeologi seharusnya mampu menjadi media bagi masyarakat untuk berefleksi dengan masa lalu dan budaya mereka, untuk menjawab dinamika masalah sosial yang ada saat ini. Termasuk memainkan peran pemberdayaan budaya, untuk melestarikan adat lokal. Adalah sangat mungkin jika arkeologi juga mendorong masyarakat untuk menjadi kontributor dalam publikasi arkeologi. Bukan saja disikusi, anamun juga memfasilitasi masyarkat utnuk menjadi kontributor dalam penerbitan ataupun pameraan. Luasnya segmen masyarkat, harus mendorong arkeologi untuk lebih proaktif dan kreatif alam menciptakan dan menggunakan berbagai media guna kepentingan publikasi hasil penelitian. Media konvensional seperti penenrbitan harus dilanjutkan dan dikembangkan dengan format yang lebih populer dan menjangkau khalayak yang lebih luas. Intraksi dengan mediamedia cetak lokal juga harus dibangun, sehingga ada peluang untuk selalu dapat meciptakan ruang (bahkan secara teratur dan dalam durasi panjang) bagi publikasi arkeologi. Perkembangan
Marlon Ririmasse, Siklus Informasi : Menuju Pemasyarakatan Hasil Penelitian yang Terintegrasi .......

teknologi juga merupakan satu tununtuan yang harus diskiapi dengan tangkas. Alternatif media seperti televisi, radio, internet, maupun bentuk publikasi elektornik madiri seperti DVD, VCD, Video kelak harus menjadi bagian dari strategi publikasi arkeologi. Balar Ambon sudah berupaya memulai dengan menciptakan dokumentasi penelitian dalam bentuk film berformat VCD. Kerja sama dengan media elektronik juga sudah dibuka, melalui peliputan-peliputan ragam kegiatan Balai Arkeologi Ambon. Teknologi informasi terus berkembang, dan Balar Ambon dituntut untuk mampu berinteraksi dengan perubahan tersebut. Ke depan tentu kita semua dapat berharap, Balar Ambon juga dapat memiliki portal maya di internet untuk menampilkan berbagai informasi arkeologi dalam wilayah kerja Balar Ambon. Seiring bertambah dan berkembangnya SDM, diharapkan variasi bentuk publikasi elektronik dan didital sudah dapat dilakukan.

- Publikasi arkeologi dituntut untuk mampu menciptakan sinergi arkeologi dengan pemerintah daerah dalam upaya pemanfaatan sumber daya budaya. Dalam era otonomi ini, arkeologi dituntut untuk lebih proaktif dalam membangun hubungan kerja yang bersifat win-win dengan Pemda. Untuk itu sudah seharusnya arkeologi lebih membuka diri, dan lebih bersikap 'menciptakan dan mengantar bola' untuk membuka ruang-ruang kerjasama dengan pemerintah daerah. Kemampuan arkeologi untuk menampilkan benefit pemanfaatan sumber daya budaya dalam konteks arkeologi, jangan hanya didiamkan pada level internal. Semua konsep pengembangan sumber daya budaya yang dimiliki seharusnya disuarakan. Hanya dengan membuka diri, arkeologi akan mampu memainkan perannya dengan lebih nyata dalam memberi benefit bagi pembangunan daerah. Dalam posisi inilah arkeologi seharusnya mampu memainkan perannya dengan lebih proaktif dengan berupaya untuk selalu membagi informasi perkembangan kinerja arkeologi termasuk pengembangan dna pemanfaatan sumber daya budaya yang sudah dilakukan. Arkeologi seharusnya lebih membuka diri dengan bersifat lebih proaktif dalam mengajak pemda terlibat 
secara lebih intens dalam kegiatan-kegiatan balar. Baik berupa penelitian maupun publikasi. Dengan sikap proaktif untuk membuka diri dan menampung sudut pandang pemerintah daerah, di harapkan akan ada feed back yang sama dari pemda. Setidaknya interaksi yang sudah terjalain akan mempermudah akses arkeologi untuk terlibat dalam penyusunan rencana strategis pembangunan daerah. Sehingga arkeologi dapat terlibat secara langsung dalam mempengaruhi kebijakan yang mempertimbangkan aspek-aspek perlindungan, pelestarian, pemanfaatan, dan pemasyarakatan sumber daya budaya. Suatu hal yang sangat mungkin, mengingat benefit kosnep dimaksud kembali pada pemda dan masyarkat.

Sebagai catatan, peran mediasi melalui publikasi arkeologi, sudah seharusnya mempertimbangkan upaya untuk membangun kerjasama dengan lembaga legislatif. Satu poin bagi arkeologi jika kita memiliki kemampuan untuk terlibat mendorong terciptanya perangkat undang-undang yang bermuara pada pengelolaan sumber daya budaya guna kepentingan khalayak yang seluas-luasnya.

- Mampu menciptakan sinergi dengan dunia pendidikan dan komunitas akademisi lokal. Dunia pendidikan dan Akademisi tidak dapat disangkal memiliki peran vital dalam era pembangunan daerah saat ini. Arah dan kebijakan pembangunan daerah, suka-tidak suka juga akan dipengaruhi pandangan-pandangan kelompok akademisi lokal. Di sisi lain, segmen pendidikan adalah sasaran yang jelas dalam peublikasi hasil penelitian arkeologi. Utamanya bila menilik pada tujuan memajukan pendidikan dan pengetahuan masyarakat. Arkeologi jelas memiliki peluang yang besar untuk bekerja sama baik dalam lingkup kegiatan penelitian maupun publikasi hasil penelitian dengan masyarakat pendidikan lokal. Pada segmen ini, beberapa sarana dapat diciptakan guna kepentingan publikasi hasil penelitian yang melibatkan masyarakat seperti:

- Melibatkan kalangan akademisi lokal dari bidang ilmu lain (sejarah, antropologi, dll) dalam kegiatan publikasi arkeologi. Hal ini berguna untuk saling memberi masukan dan memperkaya upaya pengembangan sumber daya budaya yang menjangkau bidang-bidang yang berkompentensi.

- Mendorong komunitas pendidikan, Guru-guru (sejarah misalnya), para pelajar untuk menjadi kontributor dalam publikasi arkeologi (penerbitan, pameran, diskusi). Upaya arkeologi menampung sudut pandang masyarakat pemaknaan sumber daya budaya, hanya dapat diimplementsikan dengan memberi ruang yang nyata bagi berbagai pemikiran versi masyarakat tersebut. Balar ambon sudah memulainya dengan melaksanakan kegiatan diskusi berskala luas guna menampung ragam sudut pandang tentang sumber daya budaya di masyarakat, termasuk kelompok akademisi, guru dan pelajar. Pada tingkat yang lebih lanjut, Bukan tidak mungkin bahwa kita bisa mengundang rekanrekan akademisi lokal, guru atau pelajar untuk memberi kontribusi dalam bentuk tulisan seputar sumber daya dalam media yang kita miliki. Bukan tidak mungkin pula kita memfasilitasi kontribusi pemikiran dan kreatifitas sekolah-sekolah melalui kegitan pameran.

- Melanjutkan dan mengembangkan sosialiasi di lingkungan pendidikan. Format sosialisasi lama yang hanya 1-2 kali dalam satu tahun kerja mungkin dapat dtingkatkan frekuensinya ddalam bentuk kerja sama dengan pihak sekolah. Misalnya menjaid 1 bulan satu kali dengan meminta waktu 1 kali pertemuan yang dirangkai dalam jam mengajar mata pelajaran sejarah untuk meberikan materi tentang arkeologi yang tentu sedapat mungkin yang bermuatan lokal. Konsep lain yang sudah umum dikenal misalnya menampung sudut pandang para pelajar dan juga guru melalui lomba karya tulis atau format lain yang sejenis. 
Denganmenjangkauketiga ranah publik ini sesungguharkeologi telah memainkan perannya untuk menciptakan strategi publikasi yang terintegrasi. Dalam arti menjangkau publik dalam artian yang seluasluasnya. Strategi untuk mencapai itu tentu perlu disusun secara cermat. Namun setidaknya bisa dimulai dengan berusaha membuka diri dan memberi ruang untuk menampung sudut padang ketiga elemen di atas dalam lingkup kerja dan publikasi arkeologi. Strategi di atas tidak lain adalah upaya Balar Ambon untuk menciptakan format pemasyarakatan hasil penelitian yang mampu untuk menstimulasi feed back dari masyarakat. Sudah pada tempatnya jika arkeologi 'membuka pintu rumahnya' dan mengundang masyarakat dalam arti luas, sebelum berharap dapat diterima juga di 'rumah' mereka. Sehingga apa yang disebut sebagai pemasyarakatan hasil penelitian yang terintegrasi akan terwujud. Yaitu bahwa arkeologi mampu menjadi mediator untuk membangun hubungan timbal balik antara semua elemen terkait dalam wacana pengembangan sumber daya budaya yang akhirnya bermuara pada terfasilitasinya kepentingan semua pihak.

\section{DAFTAR PUSTAKA}

Daud Aris Tanudirdjo, 2001

Arkeologi Pasca Modernisme Untuk Direnungkan, Makalah di sampaikan dalam Pertemuan Ilmiah Arkeologi VII, Cipanas 12-16 Maret, Proyek Penelitian Arkeologi, Jakarta, 2001.

Edy Sedyawati, 2001

Harapan Masyarakat Terhadap Kajian Arkeologi: Pengembangan Wawasan, Makalah disampaikan dalam Evaluasi Hasil Penelitian Arkeologi (EHPA) 2001, Kaliurang, Jogjakarta, 18-21 September, 2001 .

I Wayan Suantika, 2005

Visi dan Misi Balai Arkeologi Ambon, dalam Kapata Vol 1 No 1 Agustus 2005, Balai Arkeologi Ambon, Ambon.

Marlon Ririmasse, 2005

Jejak dan Prospek Penelitian Arkeologi di Maluku dalam Kapata Volume 1 No 1 Agustus 2005, Balai Arkeologi Ambon, Ambon.

Tjahjono Prasodjo, 2004

Arkeologi Publik, Makalah di sampaikan dalam Pelatihan Pengelolaan Sumber Daya Arkeologi Tingkat Dasar, Trowulan Mojokerto, 2004

Pembedayaan Masyarakat dalam Pengelolaan Sumber daya Arkeologi Makalah di sampaikan dalam Pelatihan Pengelolaan Sumber Daya Arkeologi Tingkat Dasar, Trowulan Mojokerto.

Truman Simajuntak dkk, 2003

Rencana Induk Pusat Penelitian Arkeologi, Badan Pengembangan Kebudayaan dan Pariwisata, Deputi Bidang Plesetarian dan Pengembangan Budaya, Pusat Penelitian Arkeologi, Jakarta, 2003 